\title{
INTERNATIONAL ECONOMIC LAW
}

\section{WTO Panel Rules Against U.S. Claim that Tariffs on Chinese Goods Are Justified as Necessary to} Protect "Public Morals"

doi:10.1017/ajil.2020.97

On September 15, 2020, a World Trade Organization (WTO) panel ruled that certain tariffs the United States imposed on Chinese products violated Articles I (most-favorednation) and II (tariff bindings) of the General Agreement on Tariffs and Trade (GATT). The panel rejected the U.S. attempt to invoke a "public morals" defense pursuant to GATT Article XX, holding that although countries receive substantial deference in defining "public morals," the United States failed to prove that the tariffs were necessary to achieve its stated public morals objective.

Over the past few years, the United States has engaged in an escalating trade war with China over China's trade practices. ${ }^{1}$ On August 14, 2017, President Donald Trump ordered the Office of the U.S. Trade Representative (USTR) to determine whether to "investigate any of China's laws, policies, practices, or actions that may be unreasonable or discriminatory and that may be harming American intellectual property rights, innovation, or technology development." 2 Acting under Section 301 of the Trade Act of 1974, the USTR investigated and published a report detailing its observations on a wide range of issues, including investment, technology transfer, intellectual property theft, and competition practices. ${ }^{3}$ On June 20, 2018, the United States imposed a 25 percent tariff on a list of Chinese imports (List 1 tariffs), ${ }^{4}$ and then on September 21, 2018, it instituted a 10 percent tariff on additional Chinese imports (List 2 tariffs), later increasing the List 2 tariffs to 25 percent on May 10, 2019.5

Invoking the Understanding on Rules and Procedures Governing the Settlement of Disputes (DSU), China requested consultations with the United States, which ultimately

\footnotetext{
${ }^{1}$ Jean Galbraith, Contemporary Practice of the United States, 112 AJIL 734, 751-53 (2018) (summarizing the escalating tariff conflict between the United States and China, preceding the failure of consultations).

${ }^{2}$ Addressing China's Laws, Policies, Practices, and Actions Related to Intellectual Property, Innovation, and Technology, 82 Fed. Reg. 39,007 (Aug. 17, 2017).

${ }^{3}$ See Office of the U.S. Trade Rep., Findings of the Investigation into China's Acts, Policies, and Practices Related to Technology Transfer, Intellectual Property, and Innovation Under Section 301 of the Trade Act of 1974 (2018); see also Jean Galbraith, Contemporary Practice of the United States, 112 AJIL 505, 505-06 (2018) (discussing the USTR's findings).

${ }^{4}$ Notice of Action and Request for Public Comment Concerning Proposed Determination of Action Pursuant to Section 301: China's Acts, Policies, and Practices Related to Technology Transfer, Intellectual Property, and Innovation, 83 Fed. Reg. 28,710 (June 20, 2018) [hereinafter June Notice]; see also Notice of Determination and Request for Public Comment Concerning Proposed Determination of Action Pursuant to Section 301: China's Acts, Policies, and Practices Related to Technology Transfer, Intellectual Property, and Innovation, 83 Fed. Reg. 14,906 (Apr. 06, 2018) [hereinafter April Notice].

${ }^{5}$ Notice of Modification of Section 301 Action: China's Acts, Policies, and Practices Related to Technology Transfer, Intellectual Property, and Innovation, 83 Fed. Reg. 47,974 (Sept. 21, 2018) (imposing the initial 10\% tariffs); Notice of Modification of Section 301 Action: China's Acts, Policies, and Practices Related to Technology Transfer, Intellectual Property, and Innovation, 84 Fed. Reg. 20,459 (May 9, 2019) (raising the tariffs to 25\%).
} 
failed to resolve the dispute, ${ }^{6}$ and then requested the establishment of a WTO panel. ${ }^{7}$ The panel circulated its findings on September $15,2020 .^{8}$

After disposing of two procedural objections made by the United States, the panel examined whether the tariffs were consistent with the GATT. China argued, ${ }^{9}$ and the United States did not contest, ${ }^{10}$ that the tariffs were inconsistent with Articles I:1 and II:1(a) and (b) of the GATT. The panel agreed that China established a prima facie violation of Article I: 1 because the tariffs placed the covered Chinese products at a disadvantage compared to non-Chinese products. ${ }^{11}$ The panel further concluded that the tariffs were inconsistent with Article II:1(a) and (b), which prohibit the imposition of customs duties in excess of the general Schedule rates and the Schedule rates agreed upon for certain products. ${ }^{12}$ The panel held that the tariffs were inconsistent with Article II:1(a) because they "accord imports from China 'less favourable treatment' than that provided in the United States' Schedule"13 and also inconsistent with Article II:1(b) because they were "ordinary customs duties applied in excess of the rates to which the United States bound itself in its Schedule."14

The main U.S. defense centered on its argument that the tariffs were lawfully imposed as measures "necessary to protect US public morals pursuant to Article XX(a) of the GATT 1994." 15 The United States argued that China's actions, described in the Section 301 report, violated U.S. laws, including "the prohibition of theft, extortion, cyber-enabled theft and cyber-hacking, economic espionage and the misappropriation of trade secrets, anti-competitive behaviour, as well as the regulation of governmental takings of property." 16 These practices, the United States explained, threaten U.S. "political and social institutions." 17 The United States argued that the laws prohibiting unfair trade practices codify restrictions on behavior based on "national concepts of right and wrong," and China's acts, policies, and practices violate these concepts. ${ }^{18}$

In evaluating the U.S. argument, the panel articulated a three-step test for assessing invocations of a "public morals" defense: (1) "whether the claimed policy is a 'public morals' objective within the meaning of Article XX(a)"; (2) "whether the measure is 'designed' to protect that public morals objective"; and (3) whether the measure is "necessary" to the protection of public morals. ${ }^{19}$

The panel accepted the U.S. claim that the values invoked implicated "public morals." The panel defined public morals broadly, as "a set of habits of life relating to right and wrong

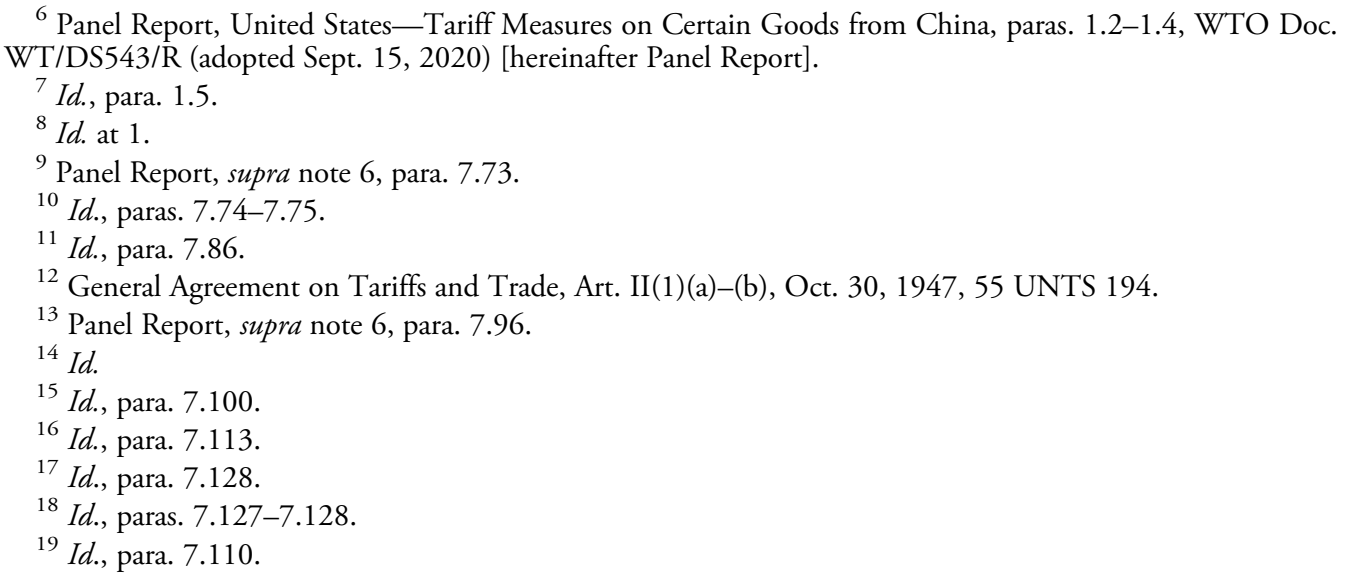


conduct (i.e. societal values) that belong to, affect or concern a community or a nation."20 The panel concluded that the "standards of right and wrong," as characterized by the United States, "could, at least at a conceptual level, be covered by the term 'public morals' within the meaning of Article XX(a) of the GATT 1994."21

The panel was equivocal about whether the measures were "designed" to achieve the stated public morals objective, ${ }^{22}$ but it rejected the U.S. position on the "necessity" requirement. ${ }^{23}$ The panel began with the three factors "traditionally assessed" when determining necessity: the importance of the pursued policy objective; the restrictive impact of the measures on trade; and the contribution of the measures to the pursued objective. ${ }^{24}$ The panel granted that the United States considered its objective "important," 25 but found that the tariffs still had "significant effects on international trade." 26

On the final factor of contribution, the panel stated that "contribution exists 'when there is a genuine relationship of ends and means between the objective pursued and the measure at issue." 27 The United States asserted that the tariffs create additional costs that diminish China's incentive to continue its practices, while also reducing "the incentive for US actors to engage in similar practices." 28

The panel noted that the United States had the burden of proving a sufficient relationship between the tariffs and public morals. ${ }^{29}$ The United States argued that there was a "clear and direct relationship" between the products covered by the List 1 tariffs and the Chinese actions highlighted in the Section 301 report. ${ }^{30}$ The panel examined the Notices the United States had issued listing products to be covered by the tariffs, but found that neither the Notices themselves, nor the Section 301 Report, supported a finding of contribution. ${ }^{31}$ The panel emphasized that the types of products covered by the List 1 tariffs, and the practices addressed in the Section 301 Report, did not seem strongly related. ${ }^{32}$

The panel also suggested that U.S. use of a process to exclude certain products initially included in List 1 undermined its claim that the tariffs contributed to the public morals goal. ${ }^{33}$ After initially publishing List 1 , the United States permitted interested persons to request that certain products be excluded from the list. ${ }^{34}$ Exclusions from the tariffs depended on three factors: the availability of the product from countries other than China; economic harm to the requestor or "other US interests"; and the strategic importance or relationship of

${ }^{20} I d$., para. 7.115.

${ }^{21}$ Id., paras. 7.138-7.140.

${ }^{22}$ Id., paras. 7.151-7.152.

${ }^{23}$ Id., para. 7.238.

${ }^{24}$ Id., paras. 7.158-7.159.

${ }^{25}$ Id., paras. 7.168-7.169.

${ }^{26} I d$., para. 7.171.

${ }^{27}$ Id., para. 7.175 .

${ }^{28} I d$., para. 7.176.

${ }^{29}$ Id., para. 7.180.

${ }^{30}$ Id., para. 7.182 .

${ }^{31}$ Id., paras. 7.186-7.192; see also June Notice, supra note 4; April Notice, supra note 4.

${ }^{32}$ Panel Report, supra note 6, paras. 7.192-7.194.

${ }^{33} I d$., para. 7.212 .

${ }^{34}$ Id., para. 7.204. 
that product to Chinese industrial programs. ${ }^{35}$ The panel noted that the first two factors "clearly pertain to economic considerations," and the third factor's purpose was ambiguous. ${ }^{36}$ The panel concluded that "the United States has not sufficiently explained why products that were initially considered to benefit from China's practices and policies . . . are excluded from the additional duties and how such exclusions do not undermine the achievement of the public morals objective as invoked by the United States." 37

The panel further concluded that the United States had not sufficiently explained the relationship between the List 2 tariffs and its public morals objective. ${ }^{38}$ Although the United States argued that the tariffs increased the economic pressure on China to alter its practices, ${ }^{39}$ the panel observed that the covered products extended beyond the scope of the Section 301 report. ${ }^{40}$ The panel also noted that the procedure for excluding products from List 2 mirrored the procedure followed for List 1 , except that it included an additional economic consideration as a basis for exclusion. ${ }^{41}$ These facts ultimately led the panel to conclude that the United States failed to adequately show the relationship between the List 2 tariffs and its public morals objective. ${ }^{42}$

In light of its determination that the United States failed to properly justify the tariffs under Article XX(a), the panel ruled that the tariffs were inconsistent with the GATT and recommended that the United States return to compliance with its obligations. ${ }^{43}$

U.S. Trade Representative Robert Lighthizer criticized the panel ruling, stating:

This panel report confirms what the Trump Administration has been saying for four years: The WTO is completely inadequate to stop China's harmful technology practices. . . . Although the panel did not dispute the extensive evidence submitted by the United States of intellectual property theft by China, its decision shows that the WTO provides no remedy for such misconduct. ${ }^{44}$

By contrast, Chinese Foreign Ministry Spokesperson Wang Wenbin praised the WTO, stating that "China always firmly supports and upholds the multilateral trading system with the WTO at its core, and respects its rules and rulings," and adding China's "hope that the US side will fully respect the ruling of the WTO panel." 45

35 Id., para. 7.203.

${ }^{36}$ Id., paras. 7.209-7.210.

${ }^{37}$ Id., para. 7.212 .

38 Id., para. 7.227.

39 Second Written Submission of the United States, United States-Tariff Measures on Certain Goods from China, paras. 60-61, WT/DS543 (Jan. 8, 2020), available at https://ustr.gov/sites/default/files/files/Issue_Areas/ Enforcement/DS/Pending/US.Sub2.fin.pdf.

${ }^{40}$ Panel Report, supra note 6, para. 7.217.

${ }^{41}$ Id., paras. 7.224-7.225.

${ }^{4}$ Id., paras. 7.226-7.227.

${ }^{4} I d$., paras. 8.1-8.2, 8.4.

${ }^{44}$ Office of the U.S. Trade Rep. Press Release, WTO Report on US Action Against China Shows Necessity for Reform (Sept. 15, 2020), at https:/ustr.gov/about-us/policy-offices/press-office/press-releases/2020/september/ wto-report-us-action-against-china-shows-necessity-reform [https://perma.cc/WM3L-4JM4].

${ }^{45}$ Min. For. Aff. People's Republic of China Press Release, Foreign Ministry Spokesperson Wang Wenbin's Remarks, Press Conference (Sept. 17, 2020), at https://www.fmprc.gov.cn/mfa_eng/xwfw_665399/ s2510_665401/t1815499.shtml [https://perma.cc/N2WH-S8XZ]. 
On October 26, the United States appealed the panel decision. ${ }^{46}$ The filing of an appeal stays the adoption of the panel report by the WTO's Dispute Settlement Body. ${ }^{47}$ However, because the United States has blocked appointment of new WTO Appellate Body members since 2017 in an effort to force reforms, ${ }^{48}$ the Appellate Body currently lacks the three members required to constitute a panel to review decisions. ${ }^{49}$ The absence of a functioning Appellate Body means that the U.S. appeal effectively blocks adoption of the panel report indefinitely. The U.S. notice of appeal states that " $[\mathrm{t}]$ he United States will confer with China so the parties may determine the way forward in this dispute." 50 Pointing to the paralysis of the Appellate Body, China characterized the appeal as an "abuse of procedural rules." 51

\section{United States Pursues Regulatory Actions Against TikTok and WeChat Over Data Security Concerns}

doi:10.1017/ajil.2020.98

The Trump administration is engaged in an ongoing legal battle against the makers of two Chinese smartphone applications, TikTok and WeChat, over their data-collection and content moderation practices. The administration has used both the International Emergency Economic Powers Act (IEEPA) and the Committee on Foreign Investment in the United States (CFIUS) in an attempt to force the companies to cease U.S. operations and, in TikTok's case, to change ownership. The administration's actions have spurred multiple legal challenges, several of which are ongoing, and for now, both TikTok and WeChat remain in operation in the United States.

The Trump administration has framed the TikTok and WeChat actions as the latest developments in the U.S. government's push to limit China's access to the sensitive data of U.S. persons. ${ }^{1}$ The Foreign Investment Risk Review Modernization Act of 2018 (FIRRMA) expanded CFIUS's mandate to cover certain investments involving "sensitive

\footnotetext{
${ }^{46}$ Notification of Appeal by the United States, United States - Tariff Measures on Certain Goods from China, WT/DS543/10 (Oct. 27, 2020).

${ }^{47}$ Dispute Settlement Rules: Understanding on Rules and Procedures Governing the Settlement of Disputes, Marrakesh Agreement Establishing the World Trade Organization, Annex 2, Art. 16.4, Apr. 15, 1994, 1869 UNTS 401, 33 ILM 1226 ("If a party has notified its decision to appeal, the report by the panel shall not be considered for adoption by the [Dispute Settlement Body] until after completion of the appeal.") [hereinafter DSU]; see also Jean Galbraith, Contemporary Practice of the United States, 114 AJIL 518, 525 (2020).

48 See Galbraith, supra note 47, at 518-19 (summarizing the pressure exerted on the Appellate Body by the Trump administration).

49 Id. at 520 .

${ }^{50}$ Notification of Appeal, supra note 46.

${ }^{51}$ Ministry of Commerce of the People's Republic of China Press Release, Statement by China at the DSB Meeting on 26 October 2020 (Oct. 29, 2020), at http://english.mofcom.gov.cn/article/newsrelease/significantnews/202010/20201003011778.shtml [https://perma.cc/H9UM-KNM7].

${ }^{1}$ Exec. Order 13,942, 85 Fed. Reg. 48,637 (Aug. 6, 2020) (TikTok); Exec. Order 13,943, 85 Fed. Reg. 48,641, (Aug. 6, 2020) (WeChat).
} 